\title{
Prevalence of BER gene polymorphisms in sporadic breast cancer
}

\author{
MOHAMED F. ALI ${ }^{1}$, JANE L. MEZA ${ }^{2}$, ELEANOR G. ROGAN $^{1}$ and DHRUBAJYOTI CHAKRAVARTI ${ }^{1}$ \\ ${ }^{1}$ Eppley Institute for Research in Cancer and Allied Diseases; ${ }^{2}$ College of \\ Public Health, University of Nebraska Medical Center, Omaha, NE, USA
}

Received September 29, 2007; Accepted November 28, 2007

\begin{abstract}
Studies suggest that breast cancer is initiated by the induction of somatic mutations from errors in the base excision repair (BER) of endogenous estrogen-induced abasic sites. If so, the inheritance of certain polymorphic mutations in BER genes involved in the incorporation and management of such errors should increase the risk of breast cancer. To test this hypothesis, we examined breast tissues from 48 women (controls, histopathologically normal tissue from reduction mammoplasty) and 40 women with breast cancer (breast tumor-adjacent, histopathologically normal tissues) for the presence of reported polymorphic mutations in four BER genes. The breast tissues were obtained from the Cooperative Human Tissue Network-western division and from the University of Nebraska Medical Center. Using PCR-RFLP procedures, the XRCC1 gene was examined for Arg194Trp and Arg399Gln, APE1 for Asp148Glu, LIG3 $\alpha$ for Arg780His and PARP1 for Pro377Ser mutations. The women in this study carried only the XRCC1 Arg399Gln polymorphism. This result was surprising because APE1 148Glu was reported to be frequently inherited (allele frequency, 0.47-0.495) by USA and European women. Thus, the USA women in our study are genetically different from those in the previous studies. Among the control women, 21 (43.75\%) were Arg/ Arg wild-types, 20 (41.67\%) were Arg/Gln heterozygotes and $7(14.6 \%)$ were Gln/Gln homozygotes. Among the breast cancer cases, 11 (27.5\%) were Arg/Arg wild-types, 16 (40\%) were Arg/Gln heterozygotes and 13 (32.5\%) were Gln/Gln homozygotes. Thus, the Gln allele was significantly more frequent in breast cancer cases (allele frequency, 0.52) than in
\end{abstract}

Correspondence to: Dr Dhrubajyoti Chakravarti, Eppley Institute for Research in Cancer and Allied Diseases, 986805 Nebraska Medical Center, Omaha, NE 68198-6805, USA

E-mail:dchakrav@unmc.edu

Abbreviations: XRCC1, X-ray cross-complementing, group 1; APE1, apurinic/apyrimidinic endonuclease 1; LIG3 $\alpha$, DNA ligase III; OGG1, 8-hydroxyguanine-DNA glycosylase; PARP1, poly (ADPribose) polymerase, member 1

Key words: APE1, XRCC1, PARP1, LIG3, polymorphism, breast cancer controls (allele frequency, 0.35), suggesting that XRCC1 399GIn may enhance the risk of breast cancer.

\section{Introduction}

Base excision repair (BER) has long been thought of as the guardian of the genome, responsible only for minimizing somatic mutations by correctly repairing endogenous base loss in DNA (1). Carcinogens that form abasic sites have been shown to induce errors in BER, forming mutations that lead to cancer (2-5).

In breast cancer, the mutations can be induced by errors in the repair of the abasic sites generated by natural estrogens (4-6). In this mechanism, estrogen metabolism in the breast is altered, leading to an abnormal increase in the levels of catechol quinones, especially the estrogen-3,4-quinones, which react with DNA and almost exclusively form depurinating adducts (7-9). These adducts spontaneously dissociate from DNA to form abasic sites and generate mutations by BER errors $(4,5)$.

If erroneous BER is a mechanism of breast cancer, the polymorphic mutations in BER genes that increase mutagenesis would be expected to modify breast cancer risk. There is a limited amount of information about BER gene polymorphisms in breast cancer $(10,11)$. Briefly, OGG1 Ser326Cys, APE1 Asp148Glu, PARP1 Val276Trp and LIG3 $\alpha$ Arg780His did not show any significant association with breast cancer (12-14). On the other hand, in some studies, polymorphisms in the XRCC1 gene (Arg194Trp, Arg280His and Arg399Gln) showed a positive association with breast cancer. For example, the XRCC1 Arg399Gln mutation was thought to increase breast cancer risk in African-American (15), Indian (16), Korean (17) and Turkish women (18). Other studies did not find a similar risk. For example, XRCC1 399Gln was not associated with breast cancer in Chinese (19) and USA women (North Carolina) $(20,21)$, but a protective effect was suggested for Portuguese women with no family history of breast cancer (22). Even though the epidemiological results are not uniform, mechanistic studies indicate that XRCC1 399Gln is detrimental to the cell. It affects BER activity (23) and increases mutagenesis in smokers $(24,25)$. On the other hand, it is inherited more frequently (up to $37 \%$ ) than the incidence rate $(\sim 13 \%)$ of breast cancer $(21,26-30)$. Therefore, XRCC1 399 Gln may be a low-penetrance variant that requires additional factors to exert its deleterious effects.

XRCC1 itself does not have a catalytic activity in BER. Nevertheless, it is critical for efficient BER as it recruits 
catalytic BER proteins and assembles them for the steps of BER (31). Since XRCC1 399GIn shows a reduced BER activity (23), it is possible that this variant may affect the recruitment of BER proteins (i.e., alter gene-gene interaction). A few studies have reported that some breast cancer patients who carry XRCC1 variants also carry additional variant BER genes $(16,20,32)$. Therefore, it is unclear whether the proposed carcinogenic effect of XRCC1 399Gln could be mediated by its interaction with wild-type BER proteins, or whether it must interact with other polymorphic BER proteins.

In addition to showing increased mutagenesis $(24,25)$, smokers who carry XRCC1 399Gln also show increased breast cancer risk $(33,34)$. These effects of smoking suggest a gene-environment interaction, which may be explained by our discovery that some smoke carcinogens produce abundant amounts of depurinating adducts that form the abasic sites (35), which induce carcinogenic mutations by erroneous BER $(2,3)$. Since estrogens induce depurinating adducts (7) and mutations by erroneous BER $(4,5)$, they may also contribute to the proposed carcinogenic activity of XRCC1 399Gln. In this study, we have examined the prevalence of BER gene polymorphisms in breast tissues in the control (reduction mammoplasty) and cancer (tumor-adjacent normal tissue) patients.

\section{Materials and methods}

Study population. Breast tissues were obtained from the University of Nebraska Medical Center (UNMC), Department of Surgery, as previously described (8), or, from the Cooperative Human Tissue Network (CHTN)-western division under a protocol approved by the UNMC Institutional Review Board. Breast tissues from women who have undergone a reduction mammoplasty were used as controls. For some, race information was not available (the unknowns). The breasts of these women were histopathologically cancer-free and their reports did not indicate previous cancer in other organs. The cases were breast tumor-adjacent, and histopathologically normal tissues from women with diagnosed primary breast cancer. Their pathology reports did not indicate additional cancers. Tissue samples were grouped as controls and cases and assigned independent serial numbers for blind analysis.

An analysis of polymorphic mutations in BER genes. Mammary tissues were ground in liquid $\mathrm{N}_{2}$ using pre-chilled mortar-and-pestles inside a biological safety hood. The ground tissues were stored frozen at $-80^{\circ} \mathrm{C}$ until use. For the analysis of the mutations, chromosomal DNA was extracted from these samples using the DNeasy tissue kit (Qiagen, Valencia, CA). Briefly, $\sim 25 \mathrm{mg}$ of the ground tissue was digested with proteinase $\mathrm{K}$ in the supplied ATL buffer $(200 \mu \mathrm{l})$ at $50^{\circ} \mathrm{C}$ until the suspension was not gelatinous $(\sim 3 \mathrm{~h})$. The digestion was stopped by adding the supplied AL buffer $(200 \mu \mathrm{l})$ and incubating for $10 \mathrm{~min}$ at $70^{\circ} \mathrm{C}$. Ethanol $(200 \mu \mathrm{l})$ was then added to the mixture, which was vortexed and the DNA purified using DNeasy mini columns with the supplied AE buffer (100 $\mu$ 1). This procedure yielded 15-20 $\mu \mathrm{g}$ DNA.

PCR-RFLP analysis of polymorphic mutations. To increase PCR efficiency, chromosomal DNAs were fragmented with
BamHI or EcoRI (avoiding cleavage within the amplicons) and RNase A, incubated with proteinase K (Invitrogen, Carlsbad, CA) and extracted with phenol/chloroform, followed by ethanol precipitation. The resulting DNAs were dissolved in nuclease-free water ( $\mathrm{pH} 7.0$, Ambion, Austin, TX) and the PCR was amplified using gene-specific primers (Table I). The amplifications were conducted as $20 \mu \mathrm{l}$ reactions in $1 \mathrm{X}$ Tth buffer (Roche, Indianapolis, IN), $2.5 \mathrm{mM}$ dNTPs, $10 \mathrm{pmol}$ primers, 1 x MasterAmp PCR enhancer (Epicentre Biotechnologies, Madison, WI), Tth DNA polymerase (1 U, Roche), Vent DNA polymerase (0.02 U, New England Biolabs, Ipswich, MA) and covered with $15 \mu \mathrm{l}$ mineral oil (ICN Biomedicals, Aurora, OH). The cycling conditions included an initial denaturation at $94^{\circ} \mathrm{C}$ for $4 \mathrm{~min}, 30$ cycles of touchdown PCR (36) involving denaturation (1 min at $94^{\circ} \mathrm{C}$ ), annealing ( $30 \mathrm{sec}$ at $65-50^{\circ} \mathrm{C}, 0.5^{\circ} \mathrm{C} /$ cycle decrements, extension $\left(30 \mathrm{sec}\right.$ at $\left.75^{\circ} \mathrm{C}\right)$, followed by 20 cycles of amplification involving denaturation $\left(30 \mathrm{sec}\right.$ at $\left.94^{\circ} \mathrm{C}\right)$, annealing $\left(30 \mathrm{sec}\right.$ at $\left.50^{\circ} \mathrm{C}\right)$, extension $\left(30 \mathrm{sec}\right.$ at $\left.75^{\circ} \mathrm{C}\right)$ and a final extension $\left(7 \mathrm{~min}\right.$ at $\left.75^{\circ} \mathrm{C}\right)$. The PCR products were separated by $1 \%$ agarose gel electrophoresis, the bands excised and DNA was recovered by using the QIAquick PCR purification kit (Qiagen). The resulting DNA samples were digested with restriction enzymes (5 U, New England Biolabs) (Table I) for $3 \mathrm{~h}$ according to vendor and examined by $3 \%$ agarose gel electrophoresis.

The primers and the restriction fragments are shown in Table I. XRCC1 codon 194 (Arg) lies within exon 6 and its mutation to Trp (CGG to TGG) forms a new PvuII site (37). XRCC1 codon 399 (Arg) is located in exon 10 and its mutation to Gln (CGG to CAG) eliminates its NciI site (38). The APE1 codon 148 (Asp) lies within exon 5 and its mutation to Glu (GAC to GAG) forms a new BfaI site (39). LIG3 $\alpha$ codon 780 (Arg) is in exon 18 and its mutation to His (CGC to CAC) results in the loss of the AciI site. PARP1 codon 377 (Pro) lies in exon 8 and its mutation to Ser (CCT to TCT) eliminates a NlaIV site. Of the breast cancer-adjacent normal tissues, there were samples from two regions in five patients. These duplicate samples were also tested by PCRRFLP to authenticate the techniques for all polymorphisms (data not shown). For further authentication, PCR products from three XRCC1 exon 6, seven XRCC1 exon 10, eight APE1 exon 5 and eight LIG3 $\alpha$ exon 18 samples were sequenced (data not shown). The results were expressed by allele frequency (e.g., variant allele frequency $=$ frequency of $\mathrm{VV}+$ frequency of $\mathrm{WV}$, where $\mathrm{V}$, variant and $\mathrm{W}$, wild-type).

Statistical analysis. The distribution of allele frequencies was compared between the cases and controls using Pearson's Chi-square test.

\section{Results}

BER gene polymorphisms in breast cancer: XRCC1 399Gln. Previous studies indicated that the XRCC1 399Gln allele is a BER gene polymorphism frequently inherited by American white women (allele frequency, 0.34-0.37) $(14,15,20,21,26-$ $29,40)$. Other ethnic groups have not been as well-studied. However, fewer American black women have been reported to carry this variant allele (frequency, $0.14-0.17)(15,21,27,29)$. 
Table I. PCR-RFLP analysis.

\begin{tabular}{|c|c|c|c|c|c|c|c|}
\hline \multirow{2}{*}{$\begin{array}{l}\text { BER gene } \\
\text { (GenBank) }\end{array}$} & \multicolumn{2}{|c|}{ PCR primers } & \multicolumn{4}{|l|}{ RFLP analysis } & \multirow[b]{2}{*}{ Ref. } \\
\hline & Genotype & Mutation & PCR primers and product & Enzyme & Genotype & Fragmentation (bp) & \\
\hline \multirow{5}{*}{$\begin{array}{l}\text { XRCC1 } \\
\text { (AF512504) }\end{array}$} & Arg 194Trp & CGG to TGG & Forward: 5'-GTTCCGTGTGAAGGAGGAGGA & $P v u \mathrm{II}$ & Arg/Arg & 138 & $(37)$ \\
\hline & & (Exon 6) & Reverse: 5'-CGAGTCTAGGTCTCAACCCTACTCACT & & Arg/Trp & $138+75+63$ & \\
\hline & Arg399Gln & CGG to CAG & Forward: 5'-CAGTGGTGCTAACCTAATC & $N c i \mathrm{I}$ & Arg/Arg & $461+278+132$ & $(38)$ \\
\hline & & (Exon 10) & Reverse: 5'-AGTAGTCTGCTGGCTCTGG & & Arg/Gln & $593+461+278+132$ & \\
\hline & & & PCR product: $871 \mathrm{bp}$ & & $\mathrm{Gln} / \mathrm{Gln}$ & $593+278$ & \\
\hline \multirow{2}{*}{$\begin{array}{l}\text { APE1 } \\
\text { (D13370) }\end{array}$} & Asp148Glu & GAC to GAG & Forward: 5'-CTGTTTCATTTCTATAGGCTA ${ }^{\mathrm{a}}$ & $B f a \mathrm{I}$ & Asp/Asp & 164 & $(39)$ \\
\hline & & (Exon 5) & Reverse: 5'-AGGAACTTGCGAAAGGCTTC & & Asp/Glu & $164+144+20$ & \\
\hline \multirow{3}{*}{$\begin{array}{l}\text { LIG3 } \alpha \\
(\mathrm{AC} 004223)\end{array}$} & Arg780His & $\mathrm{CGC}$ to $\mathrm{CAC}$ & Forward: 5'-TGTCCAAGGAGAAGGCAGAC & AciI & Arg/Arg & $96+107$ & Herein \\
\hline & & (Exon 18) & Reverse: 5'-AGCCCCCTCCCTATCCTTAC & & Arg/His & $203+96+107$ & \\
\hline & & & PCR product: $203 \mathrm{bp}$ & & His/His & 203 & \\
\hline \multirow{3}{*}{$\begin{array}{l}\text { PARP1 } \\
\text { (AF524947) }\end{array}$} & Pro377Ser & CCT to TCT & Forward: 5'-TTTGGACAAGCCAAATCCTC & NlaIV & Pro/Pro & $275+202+46$ & Herein \\
\hline & & (Exon 8) & Reverse: 5'-GCCTCAGCAATTCTTTTGCC & & Pro/Ser & $275+248+202+46$ & \\
\hline & & & PCR product: $523 \mathrm{bp}$ & & Ser/Ser & $275+248$ & \\
\hline
\end{tabular}

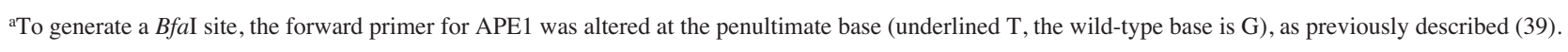
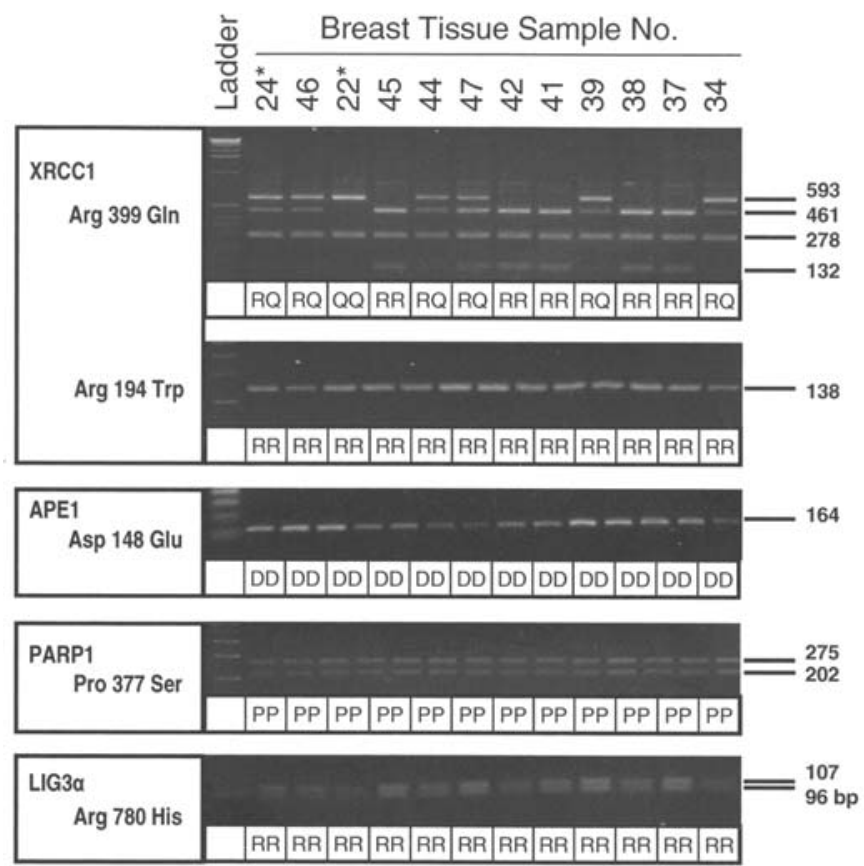

Figure 1. PCR-RFLP analysis of BER gene polymorphisms in the breast tissues of a reduction mammoplasty (control) and breast cancer (tumoradjacent normal tissue) patients. The identified genotypes are indicated by single letter codes. ${ }^{*}$ Tissues from breast cancer patients.

Women with breast cancer in the USA show this allele at a similar or slightly higher frequency (whites, 0.35-0.36 and blacks, 0.19-0.26) $(15,20,21,34)$. Chinese women also show a similar inheritance of this polymorphism (controls 0.27 and cases 0.28 ) (41). In contrast, the 399Gln allele is significantly more common in women with breast cancer than the controls in Korea (controls 0.31 and cases 0.36) (17), India (controls 0.21 and cases 0.34 ) (16), Turkey (controls 0.37 and cases 0.39 ) (18) and Finland (smokers: controls 0.27 , cases 0.30 ) (33).

We examined the XRCC1 399GIn allele in the breast tissues of USA women from 48 control (13 whites, 8 blacks, 1 Hispanic and 26 unknown) and 40 breast cancer patients (21 whites, 1 black, 1 Asian/Pacific islander and 17 unknown). Fig. 1 shows the results of a typical RFLP analysis.

In the control population, the $399 \mathrm{Gln}$ allele frequency was 0.42 among the whites (four Gln/Gln and three Arg/Gln genotypes in 13 women), 0.125 among blacks (two Arg/Gln genotypes in 8 women) and 0.40 among the unknowns (three $\mathrm{Gln} / \mathrm{Gln}$ and $15 \mathrm{Arg} / \mathrm{Gln}$ genotypes in 26 women). One control woman in the unknown group had a strong family history of breast cancer associated with a BRCA1 mutation (she was also XRCC1 399Arg/Gln). The other control women did not have a family history of breast cancer. Thus, the 399GIn allele was more frequent in our control population than previously reported (0.34-0.37).

None of the women in this study had a family history of breast cancer. Therefore, they had sporadic breast cancer. Among them, the 399Gln allele frequency was 0.55 for American whites (eight Gln/Gln and seven Arg/Gln among 21 patients) and 0.56 for the unknowns (five Gln/Gln and nine Arg/Gln among 17 patients). As in the controls, these values are higher than previously reported for USA populations (0.35-0.36). The American whites and unknown group showed 
a higher inheritance of the 399Gln allele than did the controls ( 0.55 vs. $0.42, p=0.32$ and 0.56 vs. $0.40, p=0.16$, respectively). These results support the hypothesis that the inheritance of the XRCC1 399Gln allele is a risk factor for breast cancer.

Our study did not have sufficient samples to determine whether the inheritance of the Gln/Gln or the Arg/Gln genotype was more closely associated with breast cancer risk. When the races were combined, the Gln/Gln genotype was higher in the cases than in the controls ( 32.5 vs. $14.6 \%, \mathrm{p}=0.10)$, whereas the Arg/Gln genotype was similar between the cases and controls ( 40 vs. $41.7 \%, \mathrm{p}=0.10$ ). There were more black women in our controls $(n=8)$ than cases $(n=1)$ but none of them inherited the Gln/Gln genotype. Therefore, we examined whether this apparent relationship between the Gln/Gln genotype and sporadic breast cancer held true when the black women were excluded. The Gln/Gln genotype remained higher in the cases than in the controls (33.3 vs. 17.5\%), but the results did not reach statistical significance $(\mathrm{p}=0.23)$. This trend was not observed when the analysis was restricted to the white women only (cases $38.1 \%$ and controls $30.8 \%, \mathrm{p}=0.57$ ).

Additional BER gene polymorphisms. The APE1 148Glu variant was reported at frequencies between 0.47-0.495 in the control women in Europe and the USA $(14,40,42,43)$. However, none of the 88 women in our study (48 controls and 40 cases) carried the APE1 148Glu polymorphism (Fig. 1). The absence of APE1 148Glu and the higher XRCC1 399Gln allele frequency indicated that our study population was genetically different from those reported earlier.

XRCC1 194Trp is inherited at different frequencies in different populations of which fewer American whites and blacks and Europeans were reported to carry this allele (0.04-0.11 among the controls and 0.03-0.08 among cases) than women in India, Korea and Taiwan (0.12-0.34 among the controls and 0.21-0.34 among the cases) (14-18,20,27, $29,32,42-44)$. Once more, none of the 88 women in this study carried the XRCC1 Arg194Trp allele (Fig. 1). These results support the hypothesis that women in our study were genetically different from the populations in previous studies.

We examined the inheritance of LIG3 $\alpha$ Arg780His. The 780 His allele has been reported to be rare in American white and European women (frequency, 0.001-0.002) (14,43). This allele was also absent in the 88 women in our study (Fig. 1). Therefore, the women in this study appeared to be similar to those in previous studies in their inheritance of this allele.

Finally, we examined the inheritance of PARP1 Pro377Ser. We are unaware of any previous study about its inheritance. However, the NCBI Single Nucleotide Polymorphism database (Reference SNP cluster report No. rs17577109) indicates that it is somewhat rare among controls (allele frequency, 0.014). Again, none of the 88 women in this study carried the PARP1 377Ser allele (Fig. 1). In summary, our results did not support the hypothesis that the inheritance of APE1 148Glu, XRCC1 194Trp, LIG3a 780His or PARP1 377 Ser alleles increases the risk of sporadic breast cancer.

\section{Discussion}

Several studies have suggested that the inheritance of the XRCC1 399Gln allele increases the risk of sporadic breast cancer risk (16-18,33). Our results support this conclusion. The 399Gln allele frequency was significantly higher in the breast cancer cases than in the reduction mammoplasty controls, either when the races were combined ( 0.52 vs. 0.35$)$ or the whites $(0.55$ vs. 0.42$)$ and the women of unknown races $(0.56$ vs. 0.40$)$ were considered separately. We did not obtain evidence that other BER polymorphisms (XRCC1 194Trp, APE1 148Glu, LIG3a 780His and PARP1 377Ser) contribute significantly to sporadic breast cancer risk.

The mechanism by which XRCC1 399Gln may contribute to breast cancer is unknown. Since XRCC1 is a recruiting protein for BER, the possibility exists that 399Gln acts by modifying interactions with other BER proteins. In particular, APE1 and PARP1 are candidates, because they interact with XRCC1 through the BRCT1 domain that contains codon 399 $(45,46)$. In addition, the possibility exists that a co-inheritance of XRCC1 399Gln with polymorphic variants of APE1 or PARP1 may further modify such interactions. The segment of APE1 needed to interact with the BRCT1 domain of XRCC1 has not been identified. However, one study suggested that APE1 148Glu imparts a similar hypersensitivity to ionizing radiation as does XRCC1 399Gln (39). PARP1 is known to use its own BRCT domain to bind to the BRCT1 domain of XRCC1 (45). Codon 377 of PARP1 is just upstream of this BRCT domain. The latter question could be addressed by analyzing the breast cancer risk in women who carry the XRCC1 399Gln allele as well as a PARP1 or APE1 polymorphism. However, this study did not contain a sufficient number of samples to answer this question. We conducted a power analysis to estimate the sample size requirements for detecting the effect of APE1 148Glu co-inheritance among XRCC1 399Gln carriers in causing a further increase in breast cancer risk. If the allele frequencies of XRCC1 399Gln and APE1 148Glu in the controls are 0.35 (our study) and 0.47 (previous reports), respectively, a total of 774 controls and 774 cases would be needed to detect such a gene-gene interaction at 2.00 odds ratio with $80 \%$ power at a two-sided level of significance of 0.05 .

Compared to previous reports for USA women, XRCC1 $399 \mathrm{Gln}$ was more frequent but APE1 148Glu was less frequent in our study population. Considering that the USA is a nation of immigrants, these results suggest that further studies of BER polymorphisms would be warranted.

\section{Acknowledgements}

This work was supported by a grant from the Olson Center for Women's Health, University of Nebraska Medical Center and NIH grant P20 RR017675.

\section{References}

1. Lindahl T: Suppression of spontaneous mutagenesis in human cells by DNA base excision-repair. Mutat Res 462: 129-135, 2000.

2. Chakravarti D, Mailander P, Franzen J, Higginbotham S, Cavalieri EL and Rogan EG: Detection of dibenzo[a,l]pyrene-induced H-ras codon 61 mutant genes in preneoplastic SENCAR mouse skin using a new PCR-RFLP method. Oncogene 16: 3203-3210, 1998.

3. Chakravarti D, Mailander PC, Cavalieri EL and Rogan EG: Evidence that error-prone DNA repair converts dibenzo[ $a, l]$ pyrene-induced depurinating lesions into mutations: formation, clonal proliferation and regression of initiated cells carrying H-ras oncogene mutations in early preneoplasia. Mutat Res 456: 17-32, 2000. 
4. Chakravarti D, Mailander PC, Li K-M, Higginbotham S, Zhang HL, Gross ML, Meza JL, Cavalieri EL and Rogan EG: Evidence that a burst of DNA depurination in SENCAR mouse skin induces error-prone repair and forms mutations in the H-ras gene. Oncogene 20: 7945-7953, 2001

5. Mailander PC, Meza JL, Higginbotham S and Chakravarti D: Induction of A.T to G.C mutations by erroneous repair of depurinated DNA following estrogen treatment of the mammary gland of ACI rats. J Steroid Biochem Mol Biol 101: 204-215, 2006.

6. Cavalieri E, Chakravarti D, Guttenplan J, Hart E, Ingle J, Jankowiak R, Muti P, Rogan E, Russo J, Santen R and Sutter T: Catechol estrogen quinones as initiators of breast and other human cancers: implications for biomarkers of susceptibility and cancer prevention. Biochim Biophys Acta 1766: 63-78, 2006.

7. Cavalieri EL, Stack DE, Devanesan PD, Todorovic R, Dwivedy I, Higginbotham S, Johansson SL, Patil KD, Gross ML, Gooden JK, Ramanathan R, Cerny RL and Rogan EG: Molecular origin of cancer: catechol estrogen-3,4-quinones as endogenous tumor initiators. Proc Natl Acad Sci USA 94: 10937-10942, 1997.

8. Rogan EG, Badawi AF, Devanesan PD, Meza JL, Edney JA, West WW, Higginbotham SM and Cavalieri EL: Relative imbalances in estrogen metabolism and conjugation in breast tissue of women with carcinoma: potential biomarkers of susceptibility to cancer. Carcinogenesis 24: 697-702, 2003.

9. Singh S, Chakravarti D, Edney JA, Hollins RR, Johnson PJ, West WW, Higginbotham SM, Cavalieri EL and Rogan EG: Relative imbalances in the expression of estrogen-metabolizing enzymes in the breast tissue of women with breast carcinoma. Oncol Rep 14: 1091-1096, 2005.

10. Hung RJ, Hall J, Brennan P and Boffetta P: Genetic polymorphisms in the base excision repair pathway and cancer risk: a HuGE review. Am J Epidemiol 162: 925-942, 2005.

11. Breast Cancer Association Consortium: Commonly studied single-nucleotide polymorphisms and breast cancer: results from the Breast Cancer Association Consortium. J Natl Cancer Inst 98: 1382-1396, 2006.

12. Choi JY, Hamajima N, Tajima K, Yoo KY, Yoon KS, Park SK, Kim SU, Lee KM, Noh DY, Ahn SH, Choe KJ, Han W, Hirvonen A and Kang D: hOGG1 Ser326Cys polymorphism and breast cancer risk among Asian women. Breast Cancer Res Treat 79: 59-62, 2003.

13. Vogel U, Nexo BA, Olsen A, Thomsen B, Jacobsen NR, Wallin $\mathrm{H}$, Overvad $\mathrm{K}$ and Tjonneland $\mathrm{A}$ : No association between OGG1 Ser326Cys polymorphism and breast cancer risk. Cancer Epidemiol Biomarkers Prev 12: 170-171, 2003.

14. Zhang Y, Newcomb PA, Egan KM, Titus-Ernstoff L, Chanock S, Welch R, Brinton LA, Lissowska J, Bardin-Mikolajczak A, Peplonska B, Szeszenia-Dabrowska N, Zatonski W and Garcia-Closas M: Genetic polymorphisms in base-excision repair pathway genes and risk of breast cancer. Cancer Epidemiol Biomarkers Prev 15: 353-358, 2006.

15. Duell EJ, Millikan RC, Pittman GS, Winkel S, Lunn RM, Tse CK, Eaton A, Mohrenweiser HW, Newman B and Bell DA: Polymorphisms in the DNA repair gene XRCC1 and breast cancer. Cancer Epidemiol Biomarkers Prev 10: 217-222, 2001.

16. Chacko P, Rajan B, Joseph T, Mathew BS and Pillai MR: Polymorphisms in DNA repair gene XRCC1 and increased genetic susceptibility to breast cancer. Breast Cancer Res Treat 89: 15-21, 2005.

17. Kim SU, Park SK, Yoo KY, Yoon KS, Choi JY, Seo JS, Park WY, Kim JH, Noh DY, Ahn SH, Choe KJ, Strickland PT, Hirvonen A and Kang D: XRCC1 genetic polymorphism and breast cancer risk. Pharmacogenetics 12: 335-338, 2002.

18. Deligezer U and Dalay N: Association of the XRCC1 gene polymorphisms with cancer risk in Turkish breast cancer patients. Exp Mol Med 36: 572-575, 2004.

19. Zhai X, Liu J, Hu Z, Wang S, Qing J, Wang X, Jin G, Gao J and Shen H: Polymorphisms of ADPRT Val762Ala and XRCC1 Arg399Gln and risk of breast cancer in Chinese women: a case control analysis. Oncol Rep 15: 247-252, 2006.

20. Smith TR, Levine EA, Perrier ND, Miller MS, Freimanis RI, Lohman K, Case LD, Xu J, Mohrenweiser HW and Hu JJ: DNArepair genetic polymorphisms and breast cancer risk. Cancer Epidemiol Biomarkers Prev 12: 1200-1204, 2003.

21. Pachkowski BF, Winkel S, Kubota Y, Swenberg JA, Millikan RC and Nakamura J: XRCC1 genotype and breast cancer: functional studies and epidemiologic data show interactions between XRCC 1 codon 280 His and smoking. Cancer Res 66: 2860-2868, 2006.
22. Costa S, Pinto D, Pereira D, Rodrigues H, Cameselle-Teijeiro J, Medeiros R and Schmitt F: DNA repair polymorphisms might contribute differentially on familial and sporadic breast cancer susceptibility: a study on a Portuguese population. Breast Cancer Res Treat 103: 209-217, 2007.

23. Taylor RM, Thistlethwaite A and Caldecott KW: Central role for the XRCC1 BRCT 1 domain in mammalian DNA singlestrand break repair. Mol Cell Biol 22: 2556-2563, 2002.

24. Casse C, Hu YC and Ahrendt SA: The XRCC1 codon 399 Gln allele is associated with adenine to guanine p53 mutations in non-small cell lung cancer. Mutat Res 528: 19-27, 2003.

25. Hsieh LL, Chien HT, Chen IH, Liao CT, Wang HM, Jung SM, Wang PF, Chang JT, Chen MC and Cheng AJ: The XRCC1 399Gln polymorphism and the frequency of p53 mutations in Taiwanese oral squamous cell carcinomas. Cancer Epidemiol Biomarkers Prev 12: 439-443, 2003.

26. Shen MR, Zdzienicka MZ, Mohrenweiser H, Thompson LH and Thelen MP: Mutations in hamster single-strand break repair gene XRCC1 causing defective DNA repair. Nucleic Acids Res 26: $1032-1037,1998$

27. Lunn RM, Langlois RG, Hsieh LL, Thompson CL and Bell DA: XRCC1 polymorphisms: effects on aflatoxin B1-DNA adducts and glycophorin A variant frequency. Cancer Res 59: 2557-2561, 1999.

28. Butkiewicz D, Rusin M, Enewold L, Shields PG, Chorazy M and Harris CC: Genetic polymorphisms in DNA repair genes and risk of lung cancer. Carcinogenesis 22: 593-597, 2001.

29. Stern MC, Umbach DM, van Gils CH, Lunn RM and Taylor JA: DNA repair gene XRCC1 polymorphisms, smoking, and bladder cancer risk. Cancer Epidemiol Biomarkers Prev 10: 125-131, 2001

30. American Cancer Society: Cancer Facts and Figures -2007 American Cancer Society, Atlanta, pp 1-56, 2007.

31. Vidal AE, Boiteux S, Hickson ID and Radicella JP: XRCC1 coordinates the initial and late stages of DNA abasic site repair through protein-protein interactions. EMBO J 20: 6530-6539, 2001

32. Moullan N, Cox DG, Angele S, Romestaing P, Gerard JP and Hall J: Polymorphisms in the DNA repair gene XRCC1, breast cancer risk, and response to radiotherapy. Cancer Epidemiol Biomarkers Prev 12: 1168-1174, 2003

33. Metsola K, Kataja V, Sillanpaa P, Siivola P, Heikinheimo L, Eskelinen M, Kosma VM, Uusitupa M and Hirvonen A: XRCC1 and XPD genetic polymorphisms, smoking and breast cancer risk in a Finnish case-control study. Breast Cancer Res 7 : R987-R997, 2005.

34. Shen J, Gammon MD, Terry MB, Wang L, Wang Q, Zhang F, Teitelbaum SL, Eng SM, Sagiv SK, Gaudet MM, Neugut AI and Santella RM: Polymorphisms in XRCC1 modify the association between polycyclic aromatic hydrocarbon-DNA adducts, cigarette smoking, dietary antioxidants, and breast cancer risk. Cancer Epidemiol Biomarkers Prev 14: 336-342, 2005.

35. Chakravarti D, Badawi AF, Venugopal D, Meza JL, Crandall LZ, Rogan EG and Cavalieri EL: Improved measurement of dibenzo[ $[a, l]$ pyrene-induced abasic sites by the aldehydereactive probe assay. Mutat Res 588: 158-165, 2005.

36. Don RH, Cox PT, Wainwright BJ, Baker K, Mattick JS 'Touchdown' PCR to circumvent spurious priming during gene amplification. Nucleic Acids Res 19: 4008, 1991.

37. Lee JM, Lee YC, Yang SY, Yang PW, Luh SP, Lee CJ, Chen CJ and Wu MT: Genetic polymorphisms of XRCC1 and risk of the esophageal cancer. Int J Cancer 95: 240-246, 2001.

38. Sturgis EM, Castillo EJ, Li L, Zheng R, Eicher SA, Clayman GL, Strom SS, Spitz MR and Wei Q: Polymorphisms of DNA repair gene XRCC1 in squamous cell carcinoma of the head and neck. Carcinogenesis 20: 2125-2129, 1999.

39. Hu JJ, Smith TR, Miller MS, Mohrenweiser HW, Golden A and Case LD: Amino acid substitution variants of APE1 and XRCC1 genes associated with ionizing radiation sensitivity. Carcinogenesis 22: 917-922, 2001

40. Li C, Liu Z, Wang LE, Strom SS, Lee JE, Gershenwald JE, Ross MI, Mansfield PF, Cormier JN, Prieto VG, Duvic M, Grimm EA and Wei Q: Genetic variants of the ADPRT, XRCC1 and APE1 genes and risk of cutaneous melanoma. Carcinogenesis 27: 1894-1901, 2006.

41. Shu XO, Cai Q, Gao YT, Wen W, Jin F and Zheng W: A population-based case-control study of the Arg399Gln polymorphism in DNA repair gene XRCC1 and risk of breast cancer. Cancer Epidemiol Biomarkers Prev 12: 1462-1467, 2003. 
42. Chang-Claude J, Popanda O, Tan XL, Kropp S, Helmbold I, von Fournier D, Haase W, Sautter-Bihl ML, Wenz F, Schmezer P and Ambrosone CB: Association between polymorphisms in the DNA repair genes, XRCC1, APE1, and XPD and acute side effects of radiotherapy in breast cancer patients. Clin Cancer Res 11: 4802-4809, 2005.

43. Zienolddiny S, Campa D, Lind H, Ryberg D, Skaug V, Stangeland L, Phillips DH, Canzian F and Haugen A: Polymorphisms of DNA repair genes and risk of non-small cell lung cancer. Carcinogenesis 27: 560-567, 2006.

44. Forsti A, Angelini S, Festa F, Sanyal S, Zhang Z, Grzybowska E, Pamula J, Pekala W, Zientek H, Hemminki K and Kumar R: Single nucleotide polymorphisms in breast cancer. Oncol Rep 11: 917-922, 2004.
45. Masson M, Niedergang C, Schreiber V, Muller S, Menissier-de Murcia J and de Murcia G: XRCC1 is specifically associated with poly(ADP-ribose) polymerase and negatively regulates its activity following DNA damage. Mol Cell Biol 18: 3563-3571, 1998.

46. Marsin S, Vidal AE, Sossou M, Menissier-de Murcia J, Le Page F, Boiteux S, de Murcia G and Radicella JP: Role of XRCC1 in the coordination and stimulation of oxidative DNA damage repair initiated by the DNA glycosylase hOGG1. J Biol Chem 278: 44068-44074, 2003. 